\title{
EFFECTS OF PRIOR ANNEALING ON THE MECHANICAL PROPERTIES OF A TWIST-EXTRUDED AA 7075 ALUMINUM ALLOY
}

\author{
VPLIV PREDHODNEGA ŽARJENJA NA MEHANSKE LASTNOSTI \\ ZVOJNO EKSTRUDIRANE ALUMINIJEVE ZLITINE AA 7075
}

\author{
Chandiran Sakthivel ${ }^{1}$, Velkkudi Santhanam Senthil Kumar', \\ Usuff Mohammed Iqbal ${ }^{2}$ \\ ${ }^{1}$ Department of Mechanical Engineering, College of Engineering, Guindy, Anna University, Tamil Nadu 631 561, India \\ 2Department of Mechanical Engineering, SRM Institute of Science and Technology, Kattankulathur, Chennai, 603203, India
}

Prejem rokopisa - received: 2019-04-18; sprejem za objavo - accepted for publication: 2019-09-08

doi:10.17222/mit.2019.084

\begin{abstract}
This paper discusses the mechanical properties and grain refinement of an AA 7075 aluminum alloy twist-extruded at the cold-working temperature, and variations in the properties caused by prior annealing and as a function of the mechanical properties. Post-processing properties at room temperature, namely, the tensile strength, micro-hardness and microstructure were determined. An increase in the micro-hardness and tensile strength after three passes of twist extrusion (TE) was seen when compared with the starting annealed state. When prior annealing was done at $300{ }^{\circ} \mathrm{C}$, the increase in the micro-hardness was $37 \%$ and the increase in the tensile strength was $5 \%$. The corresponding figures for prior annealing at $400{ }^{\circ} \mathrm{C}$ were $34 \%$ and $4 \%$, respectively, while for the $500{ }^{\circ} \mathrm{C}$ prior annealing, the figures were $31 \%$ and $3 \%$, respectively. However, the rate of increase in the micro-hardness and tensile strength of a sample in the annealed state was higher at $300{ }^{\circ} \mathrm{C}$ than at $400{ }^{\circ} \mathrm{C}$ or $500{ }^{\circ} \mathrm{C}$. In addition, a very fine structure of the AA 7075 aluminum alloy developed during the three TE passes as observed with a scanning electron microscope.

Keywords: twist extrusion, grain refinement, AA 7075 aluminum alloy, micro-hardness, tensile strength

V pričujočem članku avtorji opisujejo študijo sprememb mehanskih lastnosti in udrobljenje kristalnih zrn Al zlitine AA 7075, ki je bila izpostavljena hladni zvojni oz. torzijski ekstruziji (iztiskavanju). Pri tem je bilo izhodno stanje zlitine različno zaradi predhodne toplotne obdelave izvedene pri različnih temperaturah. Po izvedbi postopka hladnega iztiskavanja so pri sobni temperaturi določili natezno trdnost in mikrotrdoto zlitine ter analizirali njeno mikrostrukturo. Po treh prehodih skozi orodje za hladno zvojno ekstruzijo (TE), so avtorji študije ugotovili, da sta se povečali mikrotrdota in natezna trdnost zlitine v primerjavi z izhodnim žarjenim stanjem. Po predhodnem žarjenju pri $300{ }^{\circ} \mathrm{C}$ in iztiskavanju je mikrotrdota narasla za $37 \%$ in natezna trdnost za $5 \%$, pri $400{ }^{\circ} \mathrm{C}$ predhodnem žarjenju in iztiskavanju je mikrotrdota narasla za $34 \%$ in natezna trdnost za $4 \%$, pri $500{ }^{\circ} \mathrm{C}$ predhodnem žarjenju in iztiskavanju pa je mikrotrdota narasla za $31 \%$ in natezna trdnost za $3 \%$. Vendar pa avtorji ugotavljajo, da je bil največji prirastek mikrotrdote in natezne trdnosti izmerjen na preizkušancih, ki so bili predhodno žarjeni na $300{ }^{\circ} \mathrm{C}$ in nato zvojno ekstrudirani. Analiza mikrostrukture na vrstičnem elektronskem mikroskopu (SEM) je pokazala, da je bila v vseh primerih dosežena zelo fina oz. drobnozrnata mikrostruktura Al zlitine AA 7075 po treh prehodih skozi orodje za hladno pregibno ekstruzijo.

Ključne besede: zvojna ekstruzija, udrobljenje kristalnih zrn, Al zlitina AA 7075, mikrotrdota, natezna trdnost
\end{abstract}

\section{INTRODUCTION}

Severe-plastic-deformation (SPD) methods, applied to aluminum alloys, gained importance in advanced metal forming for producing ultrafine-grained and nanograined materials. ${ }^{1}$ However, the high cost associated with these techniques is a matter of serious concern. ${ }^{2}$ Many SPD techniques are available. These include planar $\mathrm{TE},{ }^{3}$ high-pressure torsion (HPT),${ }^{4}$ twist-channel angular pressing (TCAP), ${ }^{5}$ equal-channel angular extrusion, ${ }^{6}$ equal-channel angular pressing (ECAP), ${ }^{7}$ cold-rolled sheets, ${ }^{8}$ pressing of formed castings (piston, plunger, piston plunger and through-gate runners), ${ }^{9}$ friction-stir back extrusion (FSBE), ${ }^{10}$ simple shear extrusion, ${ }^{11}$ torsion and annealing, ${ }^{12}$ torsion,,${ }^{13}$ extrusion,,${ }^{14}$ and

*Corresponding author's e-mail:

sakthi_mech2008@yahoo.co.in (Chandiran Sakthivel)
TE. ${ }^{15}$ A TE operation involves a hydrostatic load acting on a billet pressed by a plunger and pushed through a twisted channel with a $\beta$ angle of slope of $36^{\circ}$ and an $\theta$ angle for the a rotation of $90^{\circ} .{ }^{16}$ The specimen shape remains unchanged after TE.

The effect of multiple passes on the strain suffered by a material was already studied. ${ }^{17,18} \mathrm{M}$. Iqbal et al. ${ }^{19}$ established grain refinement in the AA 7075-T6 aluminum alloy and its mechanical properties showed an improvement due to TE involving multiple passes. S. R. Bahadori et al. ${ }^{7}$ examined the grain size and micro-hardness variations in pure aluminum using different SPD techniques of equal-channel angular pressing (ECAP) and TE with cold rolling (CR) as the post process. R. Kulagin et al. ${ }^{20}$ carried out experiments that showed the cross-sectional flow in multilayer TE as a result of severe mixing of the material. This novel solution ${ }^{4}$ 
ensured a more efficient grain refinement with fewer passes of TE, which made the rolling after TE easier. M. Tajally et al. ${ }^{21}$ emphasized that the annealing temperature has a very significant effect on the recrystallization kinetics and its effect on the softening of aluminum alloy AA 7075. Moreover, selected TE specimens were made of the AA 7075 aluminum alloy due to its low density and high strength-to-weight ratio. Such alloys are used in various components of aerospace applications..$^{22,23}$ However, a lack of examination and improvement during the TE experiments of aluminum alloys is observed. This study aims at examining the effect of the annealing temperature on the TE behavior of aluminum alloy AA 7075 , as indicated by the post-processing mechanical properties, including the tensile strength, micro-hardness and microstructural characteristics.

\section{EXPERIMENTAL PART}

The TE experiment was performed on a four-column vertical hydraulic press with the maximum plunger load of 100 tones as shown in Figure 1. Plates of the AA 7075 aluminum alloy were fabricated into billets with a rectangular cross-section of $28 \mathrm{~mm} \times 18 \mathrm{~mm}$ and a length of $100 \mathrm{~mm}$. Then, the billets were annealed at (300, 400 and 500) ${ }^{\circ} \mathrm{C}$ for $90 \mathrm{~min}$, and cooled in a muffle furnace.

In order to develop ductility without a significant reduction in the strength of the particle structure, annealing was chosen as the most promising way to achieve a good combination of ductility and strength. A schematic representation of the TE process is shown in Figure 2. The experiments of TE were performed at a cold-working temperature $\left(T_{\mathrm{m}}\right.$ of $0.4{ }^{\circ} \mathrm{C}$ where $T_{\mathrm{m}}$ is the melting temperature on the absolute scale) after three passes at the prior-annealing temperatures (at 300, 400 and $500{ }^{\circ} \mathrm{C}$ ). The die had a twist channel of a slope line

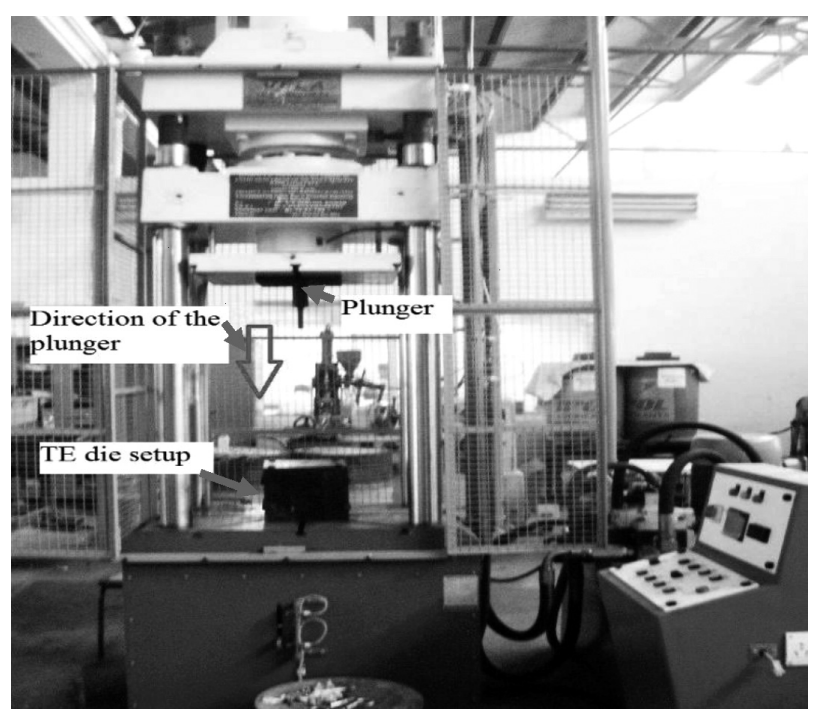

Figure 1: Four-column vertical hydraulic press for the TE forming process

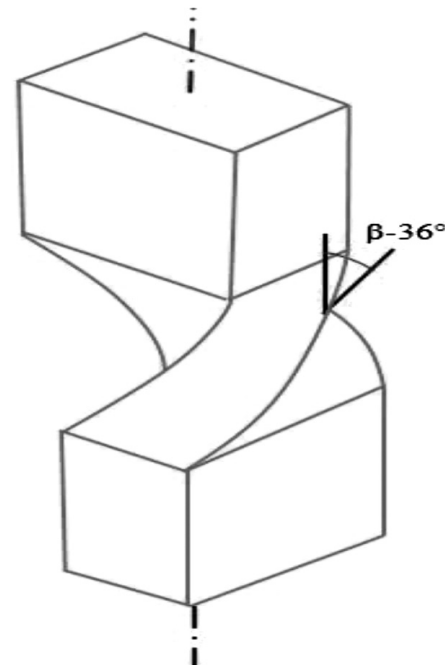

Figure 2: Schematic representation of the TE process

angle of $36^{\circ}$ and a rotational angle of $90^{\circ}$. The samples were machined to the optimal size of $28 \mathrm{~mm} \times 18 \mathrm{~mm} \times$ $100 \mathrm{~mm}$ with a vertical milling machine. The ram velocity during TE was $2 \mathrm{~mm} \mathrm{~s}^{-1}$ and a uniform force was applied with the hydraulic press. In the present experiments, two input parameters, namely the prior-annealing temperature and the number of extrusion passes were used, each of which was varied at three levels. An orthogonal array of $L_{9}$ was chosen for the TE experiments. Table 1 provides the details of the Taguchi experimental design for the $L_{9}$ orthogonal array. All these investigational conditions were applied at the prior-annealing temperature of the AA 7075 aluminum-alloy material.

Table 1: Experimental design for the TE process

\begin{tabular}{|c|c|c|}
\hline S. No. & $\begin{array}{r}\text { Prior-annealing } \\
\text { temperature }\left({ }^{\circ} \mathrm{C}\right)\end{array}$ & Number of passes \\
\hline 1 & 300 & 1 \\
\hline 2 & 300 & 2 \\
\hline 3 & 300 & 3 \\
\hline 4 & 400 & 2 \\
\hline 5 & 400 & 3 \\
\hline 6 & 400 & 1 \\
\hline 7 & 500 & 2 \\
\hline 8 & 500 & 3 \\
\hline 9 & 500 & \\
\hline
\end{tabular}

The twist-extruded samples were tested for the room-temperature tensile strength and Vickers micro-hardness (a Wolpert device) by applying a load of $500 \mathrm{~g}$ (HV $0.5 \mathrm{~kg}$ ) and a dwell time of $10 \mathrm{~s}$. The tensile samples were prepared according to ASTM-B557M-10, a standard with a fillet radius of $6.5 \mathrm{~mm}$, gauge thickness of $6 \mathrm{~mm}$ and gauge length of $28 \mathrm{~mm}$. For the microstructure investigation, the pieces were polished and etched with Keller's reagent. Microstructure and elemental-composition studies were conducted using a Hitachi S-3400 N-type scanning electron microscope (SEM) with energy-dispersive X-ray spectroscopy (EDS). The 
C. SAKTHIVEL et al.: EFFECTS OF PRIOR ANNEALING ON THE MECHANICAL PROPERTIES ...

Table 2: Experimental results for the micro-hardness and tensile strength of the AA 7075 aluminum alloy subjected to TE

\begin{tabular}{|c|c|c|c|c|c|c|}
\hline S. No. & Sample state & $\begin{array}{l}\text { Tensile strength } \\
(\mathrm{MPa})\end{array}$ & $\begin{array}{l}\text { Percentage increase in } \\
\text { the tensile strength }(\%)\end{array}$ & $\begin{array}{l}\text { Micro- hardness } \\
(\mathrm{HV})\end{array}$ & \multicolumn{2}{|c|}{$\begin{array}{l}\text { Percentage increase in the } \\
\text { micro-hardness }(\%)\end{array}$} \\
\hline 1 & \multirow{4}{*}{$500{ }^{\circ} \mathrm{C}$} & As-annealed & 396.5 & - & 87 & \\
\hline 2 & & One pass & 400.6 & 1 & 107 & 23 \\
\hline 3 & & Two passes & 409.4 & 3 & 115 & 32 \\
\hline 4 & & Three passes & 411.1 & 3 & 118 & 35 \\
\hline 5 & \multirow{4}{*}{$400{ }^{\circ} \mathrm{C}$} & As-annealed & 408.3 & - & 92 & - \\
\hline 6 & & One pass & 419.5 & 2 & 111 & 21 \\
\hline 7 & & Two passes & 424.5 & 3 & 120 & 30 \\
\hline 8 & & Three passes & 426.4 & 4 & 126 & 36 \\
\hline 9 & \multirow{4}{*}{$300{ }^{\circ} \mathrm{C}$} & As-annealed & 415.0 & - & 98 & - \\
\hline 10 & & One pass & 423.3 & 2 & 117 & 19 \\
\hline 11 & & Two passes & 428.4 & 3 & 125 & 27 \\
\hline 12 & & Three passes & 436.2 & 5 & 139 & 42 \\
\hline
\end{tabular}

grain-size distribution was obtained using the ImageJ software.

\section{RESULTS AND DISCUSSION}

\subsection{Tensile strength}

The TE experiments conducted on the AA 7075 aluminum alloy were subjected to different annealing temperatures and several passes during the TE process. The three annealing temperatures were $(300,400$ and 500) ${ }^{\circ} \mathrm{C}$. Figure 3 shows the tensile-strength specimens prepared after different TE experiments. The tensile strength was measured after each pass of the extrusion. The variations in the tensile strength of the specimens in the as-annealed state and after one, two or three TE passes are shown in Table 2. The percentage increase as a result of each of these changes is also included in Table 2. The room-temperature tensile strength of the samples annealed at $\left(300,400\right.$ and 500) ${ }^{\circ} \mathrm{C}$ increased from $415 \mathrm{MPa}$ to $436.2 \mathrm{MPa}$, from $408.3 \mathrm{MPa}$ to 426.4 $\mathrm{MPa}$ and from $396.5 \mathrm{MPa}$ to $411.1 \mathrm{MPa}$, respectively, after three passes of TE. The increase in the tensile strength of the specimens in the annealed state, at (300, 400 and 500) ${ }^{\circ} \mathrm{C}$, and TE-processed during three passes were about $5 \%, 4 \%$ and $3 \%$, respectively.

Therefore, the TE processing at $300{ }^{\circ} \mathrm{C}$ was seen as a more effective grain refinement compared with the processing at a higher temperature. After three passes of the TE experiments, the tensile-strength rate resulted in

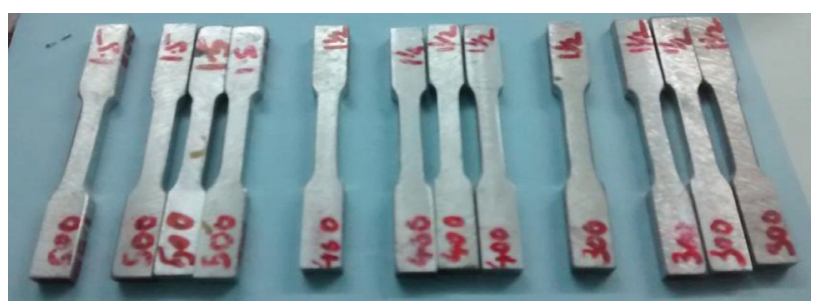

Figure 3: Samples before the tensile-strength testing and after annealing at different temperatures $\left(500,400\right.$ and 300) ${ }^{\circ} \mathrm{C}$ and then subjected to different TE steps the minimum rate of enhancement in the samples priorannealed at $400{ }^{\circ} \mathrm{C}$ and $500{ }^{\circ} \mathrm{C}$. An improvement in the TE samples ${ }^{12,24}$ was expected to occur at a lower priorannealing temperature and an increased number of passes.

Figure 4 shows the tensile-strength values corresponding to different annealing treatments with various passes of TE. The prior-annealing temperature of $300{ }^{\circ} \mathrm{C}$ and the increasing number of passes during TE clearly cause an increase in the tensile strength.

\subsection{Micro-hardness}

Table 2 summarizes the variations in the microhardness before and after TE with 1, 2 and 3 passes. Micro-hardness was measured at three locations for each sample and the average value was reported. After three passes of TE, the micro-hardness of the samples annealed at $(500,400$ and 300$){ }^{\circ} \mathrm{C}$ showed increases from $87 \mathrm{HV}$ to $118 \mathrm{HV}$ (a nearly $35-\%$ increase), from $92 \mathrm{HV}$ to $126 \mathrm{HV}$ (a nearly 36-\% increase) and from 98 $\mathrm{HV}$ to $139 \mathrm{HV}$ (a nearly 42-\% increase), respectively, as shown in Table 2. A comparison of these three annealed states led to a conclusion that the micro-hardness after the annealing at $300{ }^{\circ} \mathrm{C}$ and after three passes of TE was

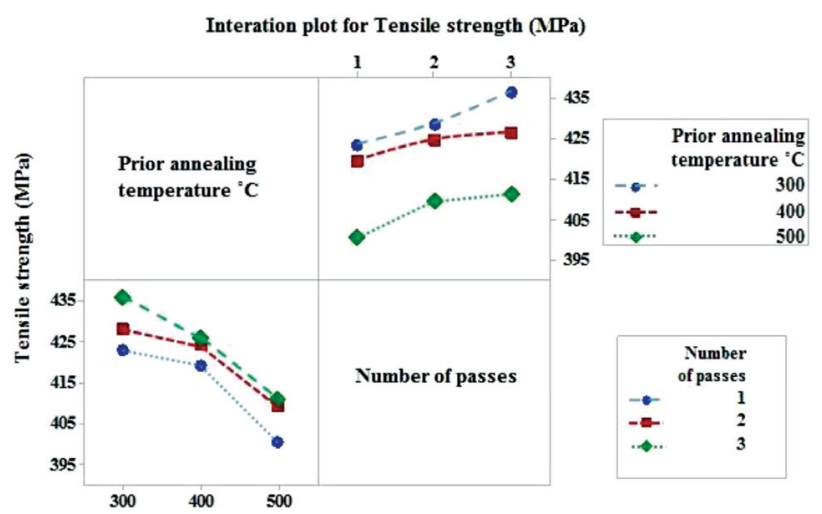

Figure 4: Tensile-strength values corresponding to different treatments 


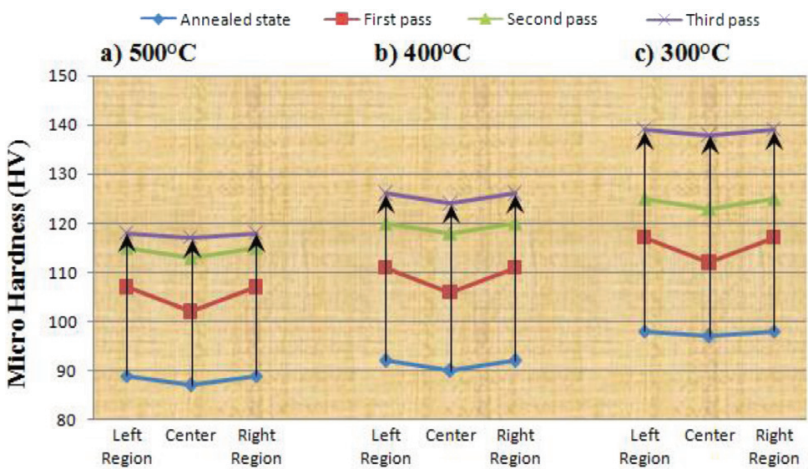

Figure 5: Micro-hardness at different locations before and after $\mathrm{TE}$ for the billets of the AA 7075 aluminum alloy annealed at different temperatures: a) $500{ }^{\circ} \mathrm{C}$, b) $400{ }^{\circ} \mathrm{C}$ and c) $300{ }^{\circ} \mathrm{C}$

higher than after the annealing at $400{ }^{\circ} \mathrm{C}$ or $500{ }^{\circ} \mathrm{C}$ as the formations of $\mathrm{MgZn}_{2}$ and $\mathrm{MgZn}$ were observed. The creation of an enhanced cyclic-torsion effect in the billet, due to TE with an increased number of passes, was found. This effect led to a finer grain structure and improved mechanical properties. Besides, the micro-hardness was also measured along the transverse section (the left side, center and right side) on the cross-section at $90^{\circ}$ to the TE direction and the results are presented in Figure 5.

The hardness of the billets was found to be $117 \mathrm{HV}$ and $118 \mathrm{HV}$ in the middle and the peripheral region on the transverse section (a nearly 1-\% increase), respectively, after three TE passes for the material annealed at $500{ }^{\circ} \mathrm{C}$. For the samples TE-processed after prior annealing at $400{ }^{\circ} \mathrm{C}$ and $300{ }^{\circ} \mathrm{C}$, the micro-hardness in the middle and in the peripheral regions of the billets was $124 \mathrm{HV}$ and $126 \mathrm{HV}$ (a nearly 1-\% increase) and $138 \mathrm{HV}$ and $139 \mathrm{HV}$ (a nearly 1-\% increase), respectively. However, the conclusion was that the percentage variation was of a very minimum value in the TE experimental investigation. A larger strain was achieved at the corner location than at the center region as shown by the micro-hardness results. The billet peripheral areas suffered plastic deformation during TE due to the contact between the billet and the die and the shear distortion in

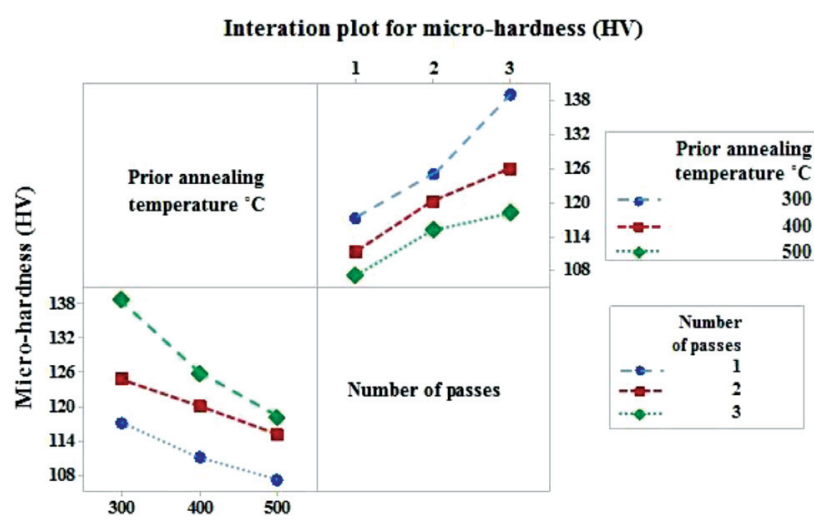

Figure 6: Micro-hardness values for the AA 7075 aluminum alloy corresponding to different treatments those regions compared with the central region of the billet. This observation was consistent with the earlier results. ${ }^{16,25}$ This variation in the strain distribution was reduced by the performance of the increasing TE passes. ${ }^{26}$ The TE experiments made the micro-hardness more homogeneous compared to the other severe plastic-deformation techniques. Figure $\mathbf{6}$ shows the micro-hardness values corresponding to different annealing treatments with various TE passes. It is observed that the prior-annealing temperature of $300{ }^{\circ} \mathrm{C}$ and the increased number of passes during TE tend to increase the micro-hardness. However, the specimen that underwent prior annealing at $300{ }^{\circ} \mathrm{C}$ exhibited a higher hardness than those annealed at $400{ }^{\circ} \mathrm{C}$ and $500{ }^{\circ} \mathrm{C}$, due to the formations of $\mathrm{MgZn}_{2}$ and $\mathrm{MgZn}$ and the particle refinement.

\subsection{Microstructure}

A TE billet was characterized using a SEM (Figure 7). A microstructural investigation of the structural changes led to the observation of the formation of various precipitates formed (Figure 7a to 7c) in the AA 7075 aluminum alloy when annealed at various temperatures for a constant annealing time.

Phase precipitates of $\mathrm{MgZn}, \mathrm{MgZn}_{2}$ (at the prior-annealing temperature of $300{ }^{\circ} \mathrm{C}$ and $400{ }^{\circ} \mathrm{C}$ ), $\mathrm{Al}_{2} \mathrm{Cu}$ and $\mathrm{AlCuMg}$ (at the prior-annealing temperature of $300{ }^{\circ} \mathrm{C}$ and $500{ }^{\circ} \mathrm{C}$ ) were formed from the supersaturated solid solution, which was confirmed through an
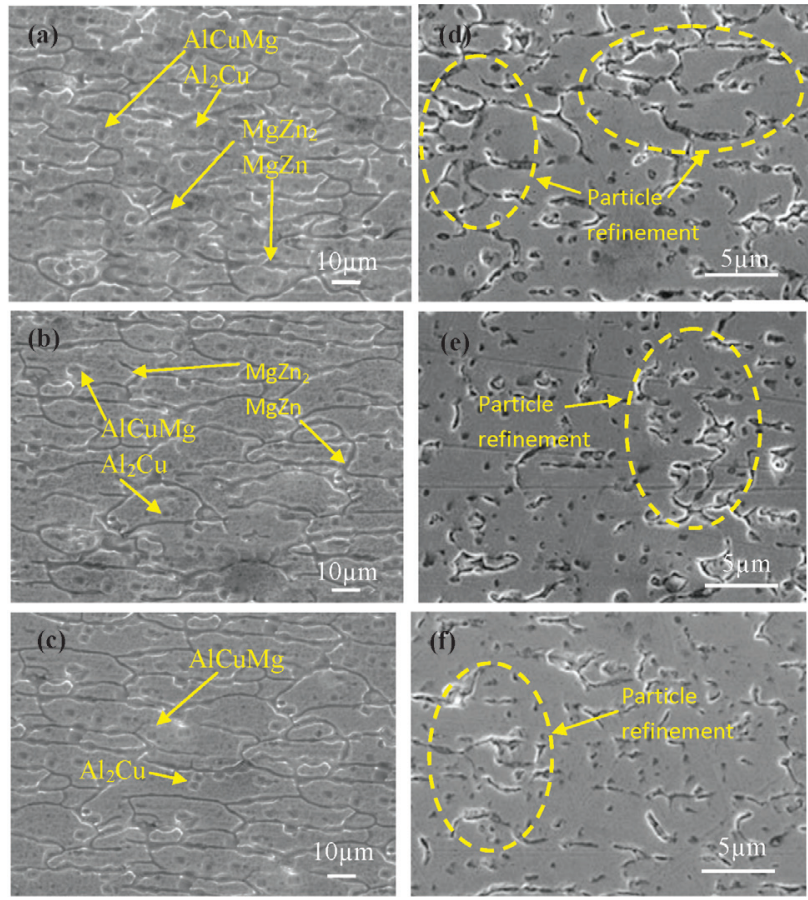

Figure 7: SEM surface morphologies of the AA 7075 aluminum alloy in the starting condition prior to $\mathrm{TE}$ and after three TE passes: annealed at: a) $300{ }^{\circ} \mathrm{C}$, b) $400{ }^{\circ} \mathrm{C}$, c) $500{ }^{\circ} \mathrm{C}$; and after TE: d) three passes after annealing at $300{ }^{\circ} \mathrm{C}$, e) three passes after annealing at $\left.400{ }^{\circ} \mathrm{C}, \mathrm{f}\right)$ three passes after annealing at $500{ }^{\circ} \mathrm{C}$ 

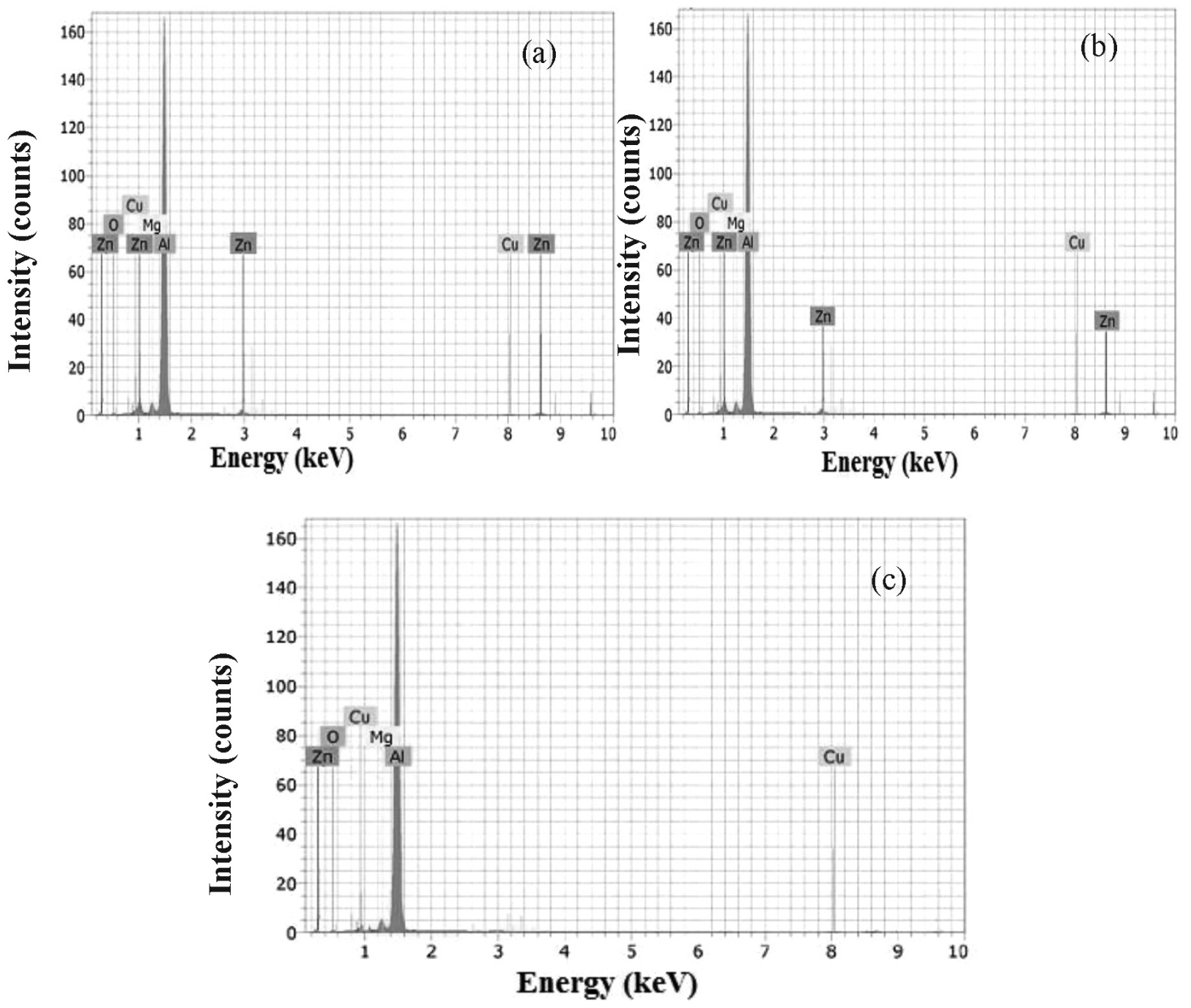

Figure 8: EDX analysis after prior annealing at: a) $300{ }^{\circ} \mathrm{C}$, b) $400{ }^{\circ} \mathrm{C}$, c) $500{ }^{\circ} \mathrm{C}$

EDS analysis as shown in Figure 8a to 8c. The annealed state suggests a reduction of the intermetallic precipitates and dissolution of the $\mathrm{Mg}, \mathrm{Zn}$ and $\mathrm{Cu}$ grains in the $\mathrm{Al}$ matrix. The same results were reported for the isothermal annealing process. ${ }^{27}$ The examination showed minimum dislocations within the grains after the first pass and a significant increase in the dislocations after three TE passes. Figure 7d to $\mathbf{7 f}$ shows a significant change in the particle structure observed in a deformed TE billet. ${ }^{22}$

To depict the grain refinement, one can utilize the model proposed by $\mathrm{H}$. Zendehdel et al. ${ }^{25}$ based on the idea that once a plastic deformation starts, dislocation density increases bringing about the development of sub-boundaries that block separation developments. Progressively, due to the aggregation of forced plastic strains and misorientation of the adjoining grains, the stretched grains tend to split into smaller grains forming an equiaxed microstructure. This is a phenomenon similar to the one seen in SPD procedures, called a unique continuous recrystallization. New grains are formed with the increased number of TE passes. ${ }^{28}$ The plastic flow during TE is defined by two principal processes: a) A vortex-like billet that flows with the strain gradient stretches across one path of the material elements and their mixture. The grain elongation and bending in successive TE passes are seen. b) A constant lamellarflow pattern is noticeable with the increased number of TE processes. ${ }^{29}$ The net effect is the accumulation of the micro-strains within the grains. ${ }^{30}$ With the increased number of TE passes, the formation of fine, new grains with small-angle boundaries, which, with further strain, become converted into grains of high-angle boundaries, is in place during the TE processes. The grain size becomes finer and the microstructure becomes more homogeneous. This is confirmed with the ImageJ software. ${ }^{31,32}$

\section{CONCLUSIONS}

The effects of prior annealing and the TE process with various passes on the mechanical characteristics of 
AA 7075 aluminum-alloy samples were studied. The following conclusions are drawn from the results of the investigation.

The two major factors that influence a billet's tensile strength and micro-hardness are the prior-annealing temperature and the increased number of TE passes. The TE experiments show an enhancement in the billet micro-hardness and tensile strength by $35-42 \%$ and 3-5\%, respectively.

According to the investigation, there was an increase in the micro-hardness and tensile strength of a specimen with a higher number of passes after prior annealing at $300{ }^{\circ} \mathrm{C}$ due to the development of strengthening phases $\left(\mathrm{MgZn}_{2}, \mathrm{MgZn}\right)$ and a particle refinement. However, the rates of increase in the micro-hardness and tensile strength were higher for the sample annealed at $300{ }^{\circ} \mathrm{C}$ than for the samples annealed at $400{ }^{\circ} \mathrm{C}$ and $500{ }^{\circ} \mathrm{C}$.

The micro-hardness of the billets annealed before TE was found to be $(87,92$ and 98$) \mathrm{HV}$ for the material annealed at the temperatures of $(500,400$ and 300$){ }^{\circ} \mathrm{C}$, respectively, and the micro-hardness of these specimens increased to $(118,126$ and 139) HV after three passes of TE. The tensile strength and micro-hardness found for the sample annealed at $300{ }^{\circ} \mathrm{C}$ were higher by $1.5 \%$ and $6 \%$ than those for the sample annealed at $500{ }^{\circ} \mathrm{C}$.

Several categories of precipitants including $\mathrm{MgZn}$ and $\mathrm{MgZn}_{2}$ (at prior-annealing temperatures of $300{ }^{\circ} \mathrm{C}$ and $400{ }^{\circ} \mathrm{C}$ ), $\mathrm{AlCuMg}$ and $\mathrm{Al}_{2} \mathrm{Cu}$ (at prior-annealing temperatures of $300{ }^{\circ} \mathrm{C}$ and $500{ }^{\circ} \mathrm{C}$ ) were formed. The TE effect on the microstructural changes of the AA 7075 aluminum alloy was examined. Moreover, the AA 7075 aluminum alloy achieved a very fine structure after three passes of the TE treatment.

The investigation shows that the strain of the material becomes higher between the initial pass and the final pass (the third pass), indicating an increase in the homogeneity of the strain distribution due to a higher number of passes.

\section{REFERENCES}

${ }^{1}$ S. A. A. Akbari Mousavi, S. R. Bahadori, A. R. Shahab, Numerical and experimental studies of the plastic strains distribution using subsequent direct extrusion after three twist extrusion passes, Mater. Sci. Eng.A, 527 (2010), 3967-3974, doi:10.1016/j.msea.2010.02.077 ${ }^{2}$ D. Orlov, Y. Beygelzimer, S. Synkov, V.Varyukhin, N. Tsuji, Z. Horita, Plastic flow, structure and mechanical properties in pure Al deformed by twist extrusion, Mater. Sci. Eng.A, 519 (2009), 105-111, doi:10.1016/j.msea.2009.06.005

${ }^{3}$ Y. Beygelzimer, D. Prilep, R. Kulagin, V. Grshaev, O. Varyukhin, M. Kulakov, Planar twist extrusion versus twist extrusion, J. Mater. Process. Technol., 211 (2011), 522-529, doi:10.1016/j.jmatprotec. 2010.11.006

${ }^{4}$ V. V. Stolyarov, Y.Beygelzimer, D. Orlov, R. Z. Valiev, Refinement of microstructure and mechanical properties of titanium processed by twist extrusion and subsequent rolling, Phys. Met. Metallogr., 99 (2005) 2, 204-21

${ }^{5}$ R. Kocich, M.v Greger, M. Kursa, I. Szurman, A. Machackova, Twist channel angular pressing (TCAP) as a method of increasing the efficiency of SPD, Mater. Sci. Eng.A, 527 (2010), 6386-6392, doi:10.1007/s10853-011-5768-1

${ }^{6}$ Y. Beggelzimer, D. Orlov, A. Korshunov, S. Synkov, V. Varyukhin, I. Vedernikova, A. Reshetov, A. Synkov, L. Polyakov, I. Korotchenkova, Features of twist extrusion: method, structures \& material properties, SSP, 114 (2006), 69-78, doi:10.4028/www.scientific.net/ SSP.114.69

${ }^{7}$ S. R. Bahadori, S. A. A. Akbari Mousavi, A. R. Shahab, Microstructure and mechanical properties of twist extruded pure aluminum processed by post-rolling, Adv. Mater. Res., 264-5 (2011), 183-187, doi:10.4048/www.scientific.net/AMR.264-265.183

${ }^{8}$ M. A. Gureeva, O. E. Grushko, Effect of heat treatment on the structure and properties of aluminum alloy AV, Met. Sci. Heat Treat., 54 (2012) 1-2, 75-79, doi:10.1007/s11041-012-9457-8

${ }^{9}$ K. A. Batyshev, Casting of aluminum alloys with pressure crystallization, Met. Sci. Heat Treat., 53 (2012) 9-10, 463-47, doi:10.1007/s11041-012-9416-4

${ }^{10}$ M. S. Khorrami, M. Movahedi, Microstructure evolutions and mechanical properties of tubular aluminum produced by friction stir back extrusion, Mater. Des., 65 (2015), 74-79, doi:10.1016/ j.matdes.2014.09.018

${ }^{11}$ E. Bagherpour, R. Ebrahimi, F. Qods, An analytical approach for simple shear extrusion process with a linear die profile, Mater. Des., 83 (2015), 368-376, doi:10.1016/j.matdes.2015.06.023

${ }^{12}$ J. Wang, D. Zhang, Y. Li, Z. Xiao, J. Fouse, X. Yang, Effect of initial orientation on the microstructure and mechanical properties of textured AZ31 Mg alloy during torsion and annealing, Mater. Des., 86 (2015), 526-535, doi:10.1016/j.matdes.2015.07.113

${ }^{13}$ X. Ma, F. Li, J. Cao, J. Li, H. Chen, C. Zhao, Vickers microhardness and microstructure relationship of Ti-6Al-4V alloy under cyclic forward-reverse torsion and monotonic torsion loading, Mater. Des., 114 (2017), 271-281, doi:10.1016/j.matdes.2016.11.028

${ }^{14}$ H. Huang, Z. Tang, Y.Tian, G. Jia, J.Niu, J.Pei, G. Yuan, W. Ding, Effects of cyclic extrusion and compression parameters on microstructure and mechanical properties of $\mathrm{Mg}-1.50 \mathrm{Zn}-0.25 \mathrm{Gd}$ alloy, Mater. Des., 86 (2015), 788-796, doi:10.1016/j.matdes.2015. 07.155

${ }^{15}$ C. Sakthivel, V. S. Senthil kumar, Determination of hardness and microstructure during cross plastic flow evaluation on twist extrusion processes, http://www.ijesmr.com/doc/ICAMS-17/3.pdf, 30.04.2017

${ }^{16}$ Y. Beygelzimer, V. Varyukhin, S. Synkov, D. Orlov, Useful properties of twist extrusion, Mater. Sci. Eng. A, 503 (2009), 14-17, doi:10.1016/j.msea.2007.12.055

${ }^{17}$ S. A. A. Akbari Mousavi, Sh. Ranjbabahadori, The effects of postannealing on the mechanical properties, microstructure and texture evolutions of pure copper deformed by twist extrusion process, Mater. Sci. Eng. A, 528 (2011), 1242-1246, doi:10.1016/j.msea. 2010.10.007

${ }^{18}$ D. Orlov, Y. Beygelzimer, S. Synkov, V.Varyukhin, N. Tsuji, Z. Horita, Microstructure evolution in pure Al processed with twist extrusion, Mater. Trans., 50 (2009) 1, 96-100, doi:10.2320/ matertrans.MD200802

${ }^{19}$ U. M. Iqbal, V. S. Senthilkumar, Experimental investigation and analysis of microstructure and mechanical properties on twist extrusion forming process of AA 7075-T6 aluminum alloy, Int. J. Mech. Mat., 17 (2011) 1, 24-30

${ }^{20}$ R. Kulagin, M. I. Latypov, H. S. Kim, V. Varyukhin, Y. Beygelzimer, Cross flow during twist extrusion: theory, experiment, and application, Metall. Mater. Trans. A, 44 (2013), 3211-3220, doi:10.1007/s11661-013-1661-7

${ }^{21}$ M. Tajally, Z. Huda, Recrystallization kinetics for aluminum alloy 7075, Met. Sci. Heat Treat., 53 (2011) 5-6, 213-217, doi:10.1007/ s11041-011-9371-5

${ }^{22}$ U. M. Iqbal, V. S. Senthil Kumar, Effect of process parameters on microstructure and mechanical properties on severe plastic deformation process of AA 7075-T6 aluminum alloy, Adv. Mater. 


\section{SAKTHIVEL et al.: EFFECTS OF PRIOR ANNEALING ON THE MECHANICAL PROPERTIES ...}

Res., 622-623 (2013), 705-709, doi:10.4028/www.scientific.net/ AMR.622-623.705

${ }^{23}$ K. Anganan, S. Prabagaran, M. Muthukrishnan, Experimental study and analysis of the wear properties of friction-stir-welded AA 7075-T6 and A384.0-T6 dissimilar aluminium alloys of butt joints, Mater. Tehnol., 52 (2018) 2, 201-205, doi:10.17222/mit.2017.109

${ }^{24}$ Y. Beygelzimer, V. Varyukhin, S. Synkov, D. Orlov, Kinematics of metal flow during twist extrusion investigated with a new experimental method, Mater. Sci. Eng. A, 503 (2009), 14-17, doi:10.1016/ j.jmatprotec.2008.08.022

${ }^{25} \mathrm{H}$. Zendehdel, A. Hassani, Influence of twist extrusion process on microstructure and mechanical properties of 6063 aluminum alloy, Mater. Des., 37 (2012), 13-18, doi:10.1016/j.matdes.2011.12.009

${ }^{26}$ U. M. Iqbal, V. S. S. Kumar, An analysis on effect of multi pass twist extrusion process of AA 6061 alloy, Mater. Des., 50 (2013), 946-953, doi:10.1016/j.matdes.2013.03.066

${ }^{27}$ N. Yazdian, F. Karimzadeh, M. Tavoosi, Microstructural evolution of nanostructure 7075 aluminum alloy during isothermal annealing, $\mathrm{J}$. Alloys Compd., 493 (2010), 137-141, doi:10.1016/j.jallcom.2009. 12.144
${ }^{28}$ S. Ranjbabahadori, S. A. A. Akbari Mousavi, Examination of an aluminum alloy behavior under different routes of twist extrusion processing, Mater. Sci. Eng.: A, 528 (2011), 6527-6534, doi:10.1016/j.msea.2011.04.092

${ }^{29}$ D. Orlov, Y. Todaka, M. Umemoto, Y. Beygelzimer, Z. Horita, N. Suji, Plastic flow and grain refinement under simple shear based severe plastic deformation processing, Mater. Sci. Forum, 604-605 (2009), 171-178, doi:10.4028/www.scientific.net/MSF.604-605.171

${ }^{30}$ S. R. Bahadori, S. A. Asghar, A. Mousavi, The evolution of homogeneity in a transverse cross-section of aluminum alloy profile deformed by twist extrusion, JOM 64 (2012) 5, 593-599, doi:10.1007/s11837-012-0305-5

${ }^{31}$ R. Kumari, N.Rana, Particle size and shape analysis using ImageJ with customized tools for segmentation of particles, IJERT, 4 (2015) 11, doi:10.17577/IJERTV4IS110211

${ }^{32}$ D. Manickam, S. Kumar, V. Santhanam, K. Sivagnanam, Experimental investigation of LM25 alloy reinforced with $\mathrm{SiC}, \mathrm{Gr}$ and MOA particles, Mater. Tehnol., 53 (2019) 3, 395-398, doi:10.17222/mit.2018.038 